\title{
Prevalence of winter migration to warmer destinations among Ontarians ("snowbirds") and patterns of their use of health care services: a population-based analysis
}

\author{
Salimah Z. Shariff PhD, J. Michael Paterson MSc, Stephanie N. Dixon PhD, Amit X. Garg MD PhD, \\ Kristin K. Clemens MD MSc
}

\section{Abstract}

Background: Older Canadians frequently migrate to warmer destinations for the winter season (snowbirds). Our aim was to examine the prevalence of migration to warmer destinations among Ontarians, and to compare the characteristics and use of health care services of snowbirds to those of older Ontarians who did not migrate for the winter.

Methods: We conducted a population-based analysis using health administrative databases from Ontario. We compiled 10 seasonal cohorts (2009/10 to 2018/19) of adults aged 65 or more who filled a travel supply of medications under the Ontario Drug Benefits program (snowbirds) between September and January (snowbird season). We calculated the seasonal prevalence of snowbirds per 100 Ontarians aged 65 or more. We matched each snowbird in the 2018/19 season to 2 nonsnowbirds on age and sex, and compared their characteristics and patterns of use of government-funded health care services.

Results: Over the 10-year period, 53431 to 70863 Ontarians aged 65 or more were identified as snowbirds (seasonal prevalence $2.6 \%-3.3 \%$ ). Compared to nonsnowbirds, snowbirds were more likely to be recent migrants, live in higher-income neighbourhoods, have fewer comorbidities and make more visits to primary care physicians. From January to March 2019, snowbirds accessed government-funded health care services for a median of 0 days (interquartile range [IQR] 0-1 d), compared to 4 days (IQR 2-8 d) among nonsnowbirds.

Interpretation: About 3\% of older Ontarians migrate to warmer destinations for the winter each season. Since few access health care services in Ontario from January to March, researchers are encouraged to consider the snowbird population and the impact of their absence on evaluations that assume continuous observation.

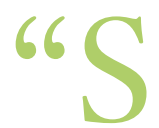
nowbird" is a colloquial term used to describe people, most often retirees, who reside in Canada or the northern United States but spend extended periods in warmer destinations, such as the southern US or Mexico, during the winter season. ${ }^{1}$ Snowbird statistics vary, with estimates ranging from 300000 to 1.4 million Canadians aged 55 or more in any given year. ${ }^{2-4}$ With an aging population and increased longevity, the number of older snowbirds is expected to increase. ${ }^{2}$ However, little is known about the contemporary snowbird population or their use of the Canadian health care system before and after they migrate for the winter. ${ }^{5-8}$ These data could support health policy-makers and providers in planning for the care needs of this population, which may differ from those of older adults who do not travel for extended periods during the winter. $^{7}$

Also unknown is the impact of overlooking snowbirds in longitudinal evaluations that rely on publicly funded health care data. In these evaluations, unobservable time while migrating to warmer destinations may result in loss of information and bias. ${ }^{9,10} \mathrm{~A}$ better understanding of the nature and characteristics of this unobservable time is first needed to appropriately advise researchers on approaches to account for this potential issue.

In Ontario, residents qualify for publicly funded prescription drug insurance through the Ontario Drug Benefit

Competing interests: Kristin Clemens reports a Diabetes Canada Junior Investigator Award sponsored by AstraZeneca, and honoraria for providing accredited continuing medical education talks from Sutherland Global Services Canada ULC and the Canadian Medical \& Surgical Knowledge Translation Research Group. She has attended Mercksponsored conferences. No other competing interests were declared.

This article has been peer reviewed.

Correspondence to: Salimah Shariff, Salimah.Shariff@ices.on.ca CMAJ Open 2021. DOI:10.9778/cmajo.20200270 
program when they turn $65 .{ }^{11}$ Beneficiaries travelling outside Ontario for extended periods are eligible to receive a travel supply of medications for a maximum of 200 days when they present proof of travel outside of the province for more than 100 days. ${ }^{12}$ As medication use in older adults is common, ${ }^{13,14}$ data on medications dispensed through the Ontario Drug Benefit program provide an opportunity to identify people who leave the province for extended periods of time (i.e., snowbirds). Leveraging this data source, we aimed to describe the prevalence of migration to warmer destinations over a 10-year period, and to compare the characteristics and patterns of use of government-funded health care services of snowbirds to those of older Ontarians who do not migrate for the winter (nonsnowbirds).

\section{Methods}

\section{Setting and design}

We conducted a population-based retrospective analysis using linked health administrative databases in Ontario. We studied consecutive cohorts of snowbirds, defined as older adults who received a travel supply of medication between September and January (the "snowbird season") from $2009 / 10$ to $2018 / 19$. This study followed the reporting guidelines for observational studies conducted using routinely collected data (RECORD statement). ${ }^{15}$

\section{Data sources}

We used 6 databases that were linked by means of encoded identifiers and analyzed at ICES, a nonprofit research institute funded by the Ontario Ministry of Health (www.ices.on. ca). Ontario Drug Benefit program claims capture outpatient prescriptions dispensed to residents aged 65 years or more, including travel supplies of medication. The Ontario Health Insurance Plan (OHIP) Claims History Database contains fee-for-service billing claims for physician and laboratory services. The OHIP Registered Persons Database contains demographic and vital status information for all OHIP registrants. The Canadian Institute for Health Information's Discharge Abstract Database and National Ambulatory Care Reporting System capture details regarding hospital admissions and emergency department visits, respectively. These data sets are detailed in Appendix 1, Supplemental Tables S1 and S2 (available at www.cmajopen.ca/content/9/2/E491/ suppl/DC1). In addition, IQVIA Solutions Canada provided information regarding the medications included in the Ontario Drug Benefit program.

\section{Cohort identification}

We assembled 10 seasonal cohorts of older adult snowbirds. For each snowbird season from 2009/10 to 2018/19, we identified Ontarians aged 65 years or more who were eligible for OHIP health coverage and who had received a travel supply of medications dispensed between Sept. 1 and Jan. 31. We applied a previously defined algorithm to distinguish travel supplies from other medication claims in the Ontario Drug Benefit program database. ${ }^{16}$ The algorithm identifies a travel supply as a medication with 100-200 days of supply (200 is the maximum permissible days' supply in the Ontario Drug Benefit program) where the beneficiary does not receive an early refill (with a second dispensing date for the same medication within $75 \%$ of the days' supply provided). In situations in which a person received a travel supply on multiple days, we considered the last dispensed medication as the index prescription, and used the date of the last prescription as the start time for follow-up. Although each seasonal cohort consisted of unique individuals, individuals could appear in more than 1 season.

For comparative purposes, we matched people included in the 2018/19 snowbird cohort on age and sex to communitydwelling Ontarians who did not receive a travel supply in the same season (nonsnowbirds) at a ratio of 1 to 2 , without replacement. There were no criteria imposed on nonsnowbird matches with respect to medications.

\section{Outcome measures}

\section{Prevalence and trends}

We measured the seasonal prevalence of migration to warmer destinations as the number of people who satisfied the definition of a snowbird per season, divided by the number of older adult Ontarians alive and eligible for provincial health coverage as of Oct. 1 of each season. We collected the characteristics of the travel supplies dispensed, including the month of prescription fill, unique number of medications dispensed, drug classes of medications dispensed and total days of supplies provided. We determined whether snowbirds in 1 season appeared again in any of the 9 other seasons.

\section{Patterns of use of government-funded health care services}

To quantify the length and interval of migration to warmer destinations, we characterized patterns of use of governmentfunded health care services in 3 periods (Appendix 1, Supplemental Figure S1). The first period spanned the 9 months preceding the index prescription date (baseline period). We summarized the total number of days in which any form of government-funded health care services was used during this baseline period and determined the longest gap in consecutive days on which health care was accessed. We defined days of use of health care services as the total number of days on which medication fills, laboratory tests, or outpatient or inpatient physician services were accessed.

The second period spanned the 9 months after the index prescription date (migration period). We used this period to identify the timing of and gap in use of government-funded health care owing to migration to warmer destinations (where health care services were not being accessed in Ontario). In addition to quantifying days on which health care was accessed and longest gap in consecutive days on which health care was accessed (migration gap), we identified the types of health care services used immediately before and after the gap, and the months during which services were used. For those who died before 
they used health care services, we used their death date as the end date for gap identification.

The third period spanned the 9 months after the end of the migration gap. We used this period to confirm that the gap in and pattern of use of health care services observed in the second period were the result of migration to warmer destinations.

\section{Statistical analysis}

We examined the sociodemographic characteristics, comorbidities and prior use of health care services among snowbirds and nonsnowbirds in 2018/19 (Appendix 1, Supplemental Table S2). For the 2009/10 snowbird cohort, we also compared single-season snowbirds to those who appeared in 2 or more seasonal cohorts over the 10 -year period (persistent snowbirds).

We conducted all analyses using SAS version 9.4 (SAS Institute). We compared characteristics descriptively and used standardized differences to examine differences between group means as a percentage of the pooled standard deviation; a difference of greater than $10 \%$ is considered noteworthy. Standardized differences are preferred over traditional hypothesis testing to assess baseline differences for population-based studies. ${ }^{17} \mathrm{We}$ used a Poisson regression model to estimate the annual change in the prevalence of migration to warmer destinations over the 10-year period. We interpreted 2-tailed $p$ values less than 0.05 as statistically significant.

\section{Ethics approval}

Our use of data in this study was authorized under section 45 of Ontario's Personal Health Information Protection Act, which does not require review by a research ethics board.

\section{Results}

\section{Prevalence and trends}

The cohort assembly is presented in Figure 1. People who were identified as snowbirds in the 2018/19 season were predominantly aged $65-79$, with less than one-fifth (12 228 [18.7\%]) aged 80 or more (Table 1). There was an even sex distribution (32 548 women [49.8\%]). In contrast to nonsnowbirds $(n=130622)$, snowbirds were more likely to reside in higher-income neighbourhoods and be a recent migrant to Ontario. They had visited the emergency department less often in the previous 12 months and had made more visits to primary care physicians in the previous 24 months (Table 1). Although they had slightly fewer comorbidities than nonsnowbirds, they were more likely to have been diagnosed with hypertension.

Annually, the number of snowbirds ranged from 53431 to 70863 (Figure 1), with a prevalence of 2.6-3.3 per 100 Ontarians aged 65 years and older (Figure 2). The prevalence increased steadily from $2009 / 10$ to $2014 / 15$ and declined thereafter, resulting in an average decrease of $1.35 \%$ (95\% confidence interval $-1.4 \%$ to $-1.26 \%$ ) over the 10 -year period.

Characteristics of single-season and persistent snowbirds in the $2009 / 10$ season are presented in Table 2 . Nearly $80 \%$

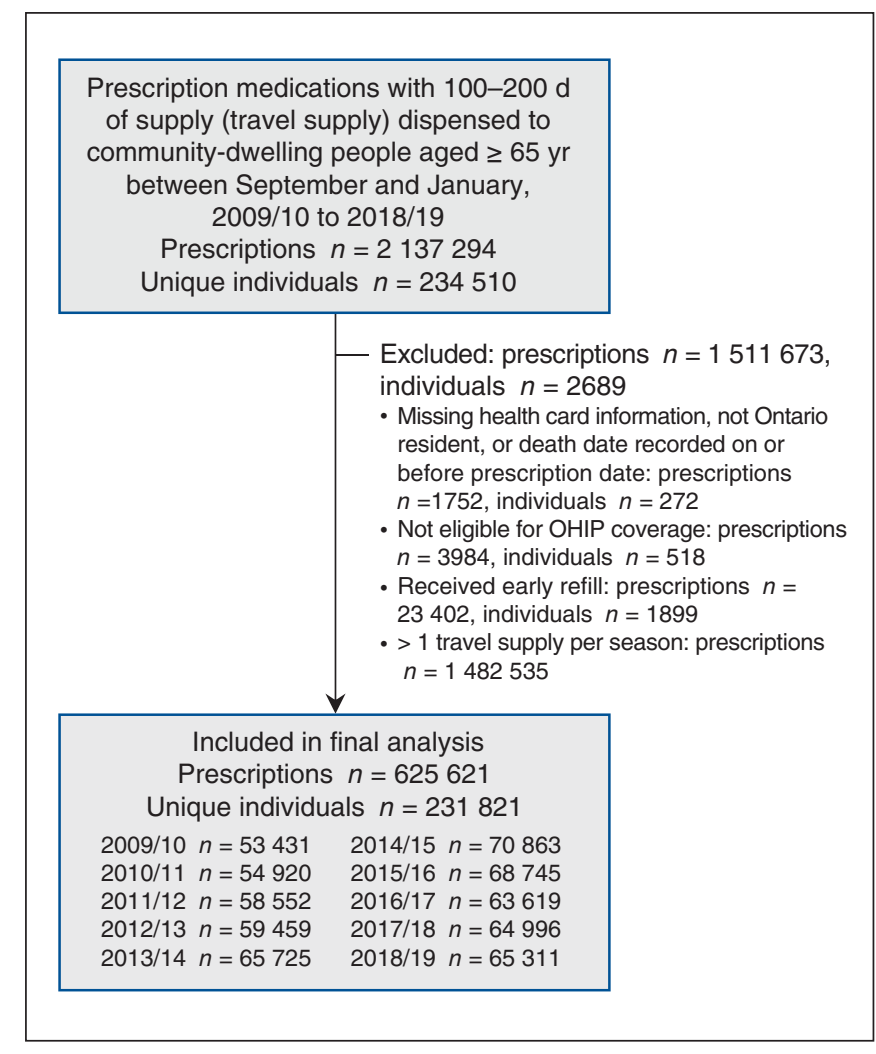

Figure 1: Flow diagram showing assembly of cohort of Ontarians aged 65 years or more who filled a prescription for a travel supply of medications between September and January from 2009/10 to 2018/19. Note: OHIP = Ontario Health Insurance Plan.

(41 805/53 431 [78.2\%]) of snowbirds in that season were identified as snowbirds in the subsequent 9 seasons. Compared to single-season snowbirds, persistent snowbirds were more likely to be evenly distributed between the sexes, younger, live in urban neighbourhoods and have fewer comorbidities. They were also less likely to be recent migrants to Ontario and to have visited primary care physicians less often in the previous 24 months.

\section{Patterns of use of government-funded health care services}

Characteristics of travel supplies of medications for the 2009/10 and 2018/19 snowbird cohorts are presented in Table 3. In both cohorts, prescriptions for travel supplies were filled predominantly between October and December, for a median of 3 distinct medications. Although the prevalence of specific medication classes shifted over the 10-year study period, prescriptions for statins, antihypertensives and orally administered antiglycemics remained among the most frequently filled. Nearly $50 \%$ of snowbirds who filled a prescription for a travel supply in 1 season did so the next season (Appendix 1, Supplemental Table S3).

In the 2018/19 snowbird cohort, the longest gap in consecutive days on which health care services were used in the baseline period was a median of 53 days (interquartile range [IQR] 36-75 d) (Table 4). In the migration period, there was nearly 


\begin{tabular}{|c|c|c|c|}
\hline \multirow[b]{2}{*}{ Characteristic } & \multicolumn{2}{|c|}{ No. $(\%)$ of people* } & \multirow{2}{*}{$\begin{array}{c}\text { Standardized } \\
\text { difference, } \\
\% \dagger\end{array}$} \\
\hline & $\begin{array}{l}\text { Snowbirds } \\
n=65311\end{array}$ & $\begin{array}{c}\text { Nonsnowbirds } \\
n=130622\end{array}$ & \\
\hline \multicolumn{4}{|l|}{ Sociodemographic characteristics } \\
\hline \multicolumn{4}{|l|}{ Age category, yr } \\
\hline $65-69$ & $17135(26.2)$ & $34244(26.2)$ & 0.00 \\
\hline $70-74$ & 20850 (31.9) & 41707 (31.9) & 0.00 \\
\hline $75-79$ & $15098(23.1)$ & $30200(23.1)$ & 0.00 \\
\hline$\geq 80$ & $12228(18.7)$ & $24471(18.7)$ & 0.00 \\
\hline Female sex & $32548(49.8)$ & $65099(49.8)$ & 0.00 \\
\hline Recent migrant to Ontarioł & $5746(8.8)$ & $5612(4.3)$ & 0.18 \\
\hline Rural residency & $10124(15.5)$ & $16856(12.9)$ & 0.07 \\
\hline \multicolumn{4}{|l|}{ Neighbourhood income quintile } \\
\hline 1 (lowest) & $9406(14.4)$ & $25298(19.4)$ & 0.13 \\
\hline 2 & 12585 (19.3) & $27050(20.7)$ & 0.04 \\
\hline 3 & $14304(21.9)$ & $26220(20.1)$ & 0.04 \\
\hline 4 & $13531(20.7)$ & $25019(19.2)$ & 0.04 \\
\hline 5 (highest) & $15373(23.5)$ & $26816(20.5)$ & 0.07 \\
\hline Missing & $112(0.2)$ & $219(0.2)$ & 0.00 \\
\hline \multicolumn{4}{|l|}{ Comorbidities } \\
\hline \multicolumn{4}{|l|}{$\begin{array}{l}\text { Deyo-Charlson Comorbidity Index } \\
\text { score }\end{array}$} \\
\hline 0 & $51806(79.3)$ & $99559(76.2)$ & 0.07 \\
\hline 1 & $6281(9.6)$ & $12533(9.6)$ & 0.00 \\
\hline$\geq 2$ & $7224(11.1)$ & $18530(14.2)$ & 0.09 \\
\hline Diabetes mellitus & $21538(33.0)$ & $38657(29.6)$ & 0.07 \\
\hline Asthma & $7854(12.0)$ & $16377(12.5)$ & 0.02 \\
\hline Chronic obstructive pulmonary disease & $9759(14.9)$ & $24408(18.7)$ & 0.10 \\
\hline Hypertension & $46438(71.1)$ & $84364(64.6)$ & 0.14 \\
\hline Acute myocardial infarction & $2373(3.6)$ & $6261(4.8)$ & 0.06 \\
\hline Congestive heart failure & $3074(4.7)$ & $8259(6.3)$ & 0.07 \\
\hline Mental health condition & $10568(16.2)$ & $24476(18.7)$ & 0.07 \\
\hline \multicolumn{4}{|c|}{ No. of prior health care visits, median (IQR)§ } \\
\hline Emergency department (previous yr) & $0(0-0)$ & $0(0-1)$ & 0.15 \\
\hline Primary care (previous 2 yr) & $8(5-12)$ & $7(4-12)$ & 0.12 \\
\hline Specialist care (previous yr) & $2(0-5)$ & $2(0-5)$ & 0.05 \\
\hline \multicolumn{4}{|c|}{$\begin{array}{l}\text { Note: IQR = interquartile range. } \\
\text { *Except where noted otherwise. } \\
\text { †We used standardized differences to identify potential clinically significant differences (>10\%) between groups. } \\
\text { fResidents who became newly eligible for Ontario Health Insurance Plan coverage in the previous } 10 \text { years. } \\
\text { \$Measured in the } 1 \text { - or } 2 \text {-year period before Oct. } 1,2018 \text {. } \\
\text { १Includes minor, general and major assessments, annual examinations, geriatric care, primary mental health care, } \\
\text { hospital care, house calls, long-term care visits, vision care, palliative care, influenza and other vaccinations, office } \\
\text { laboratory procedures, allergy and other vaccinations, Papanicolaou smears, anticoagulant therapy, preoperative } \\
\text { assessments, diabetes management and smoking cessation. }\end{array}$} \\
\hline
\end{tabular}

a threefold increase in this gap (median $147 \mathrm{~d}$, IQR 110$178 \mathrm{~d}$ ), with $14.2 \%$ of snowbirds (9255/65 311]) experiencing a gap of less than 90 days, and $2.3 \%$ (1485), a gap of less than
30 days. From January to March 2019, most snowbirds did not access government-funded health care (median number of days on which health care services accessed 0, IQR 0-1). Over 


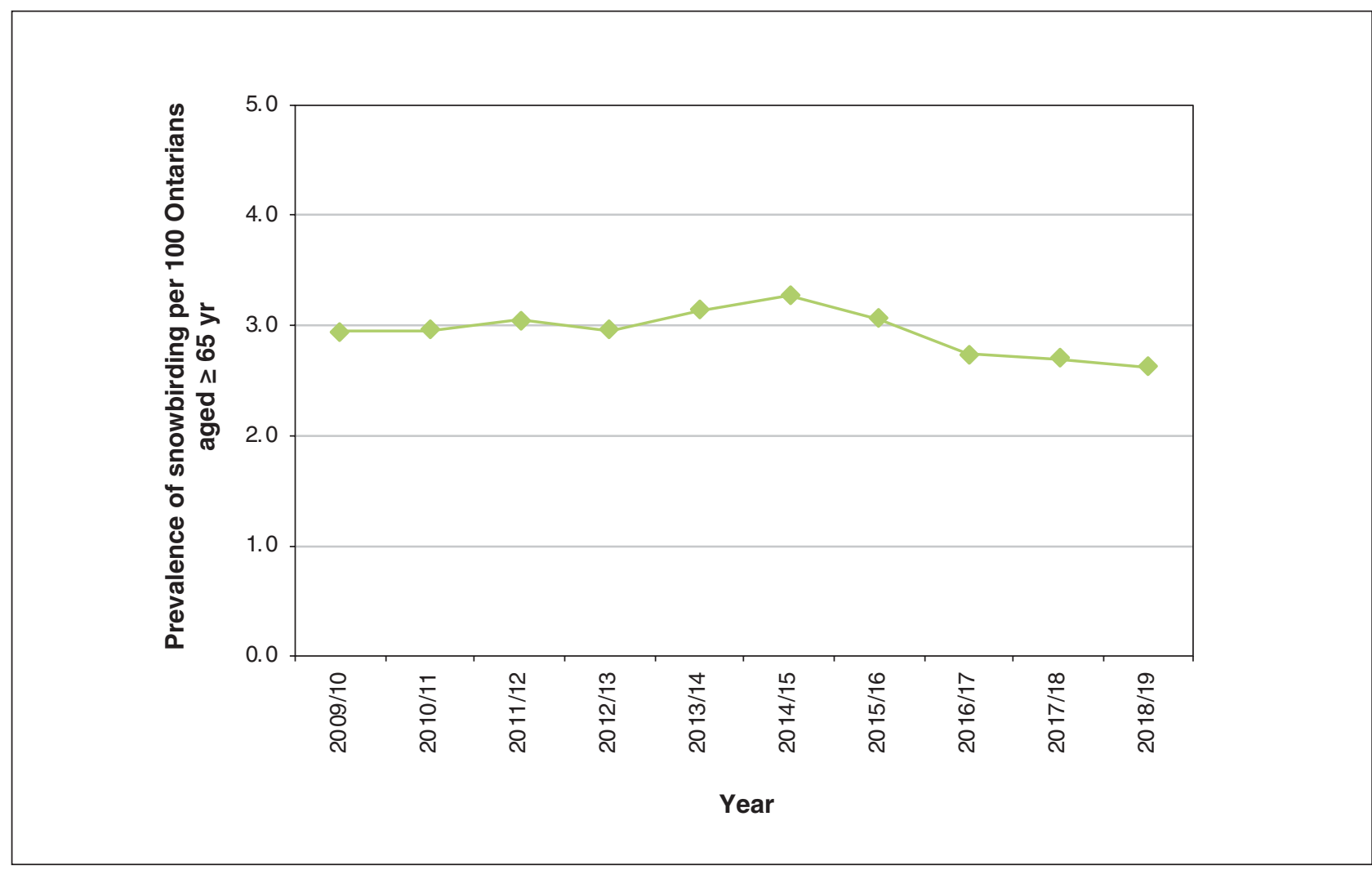

Figure 2: Prevalence of migration to warmer destinations per 100 Ontarians aged 65 years or more, 2009/10 to 2018/19.

the same period, nonsnowbirds accessed health care services on a median of 4 days (IQR 2-8 d) (Appendix 1, Supplemental Table S4).

In 2018/19, on the first day on which government-funded health care was accessed after the migration gap, snowbirds most often received outpatient physician services (36 998 [56.6\%]) or filled prescriptions (36 633 [56.1\%]) (Table 4). This occurred largely in April and May. In addition, 418 snowbirds $(0.6 \%)$ were immediately admitted to hospital, and $366(0.6 \%)$ died. Similar patterns were observed in the 2009/10 season (Table 4).

\section{Interpretation}

Statistics on emigration statistics, particularly temporary migration, are difficult to measure. ${ }^{18,19}$ In this study quantifying migration to warmer destinations during the winter season through government-funded drug claims, we estimate that $3 \%$ of Ontarians aged 65 or more snowbirded annually during the period $2009 / 10$ to $2018 / 19$. This rate falls between previously reported Canadian estimates, $1 \%-5 \% .{ }^{2-4}$ We further observed a marginal declining trend in migration to warmer destinations from 2015/16 onward, a pattern that closely aligns with trends in leisure travel to the US among Canadians owing to the weakening Canadian dollar. ${ }^{20}$

The most comprehensive study of Canadian snowbirds to date comes from a questionnaire completed by 2731 snowbirds migrating to Florida in $1986.8^{8,21-23}$ Our more contemporary analysis identified numerous similarities to the Florida sample. Like our cohorts, Florida respondents were predominantly aged 65-79, middle-class, generally healthy and well-connected to physicians. Most arrived in Florida in November and returned to Canada in April; almost all preceded their trip with a visit to their family physician and filled prescription medications for the duration of their trip. In contrast to our study, this older report identified very few recent immigrants $(<1 \%)$, which may be a result of substantially increased immigration to Canada since the 1980s. ${ }^{24}$ We noted that the prevalence of recent migrants among snowbirds was twice that among matched nonsnowbirds ( $8.3 \%$ v. $4.3 \%$ ), perhaps because recent migrants may return to their countries of origin during the Canadian winter, which may offer temperate climates, and social and familial ties. However, this practice may not be sustained over time, as persistent snowbirds were less likely than single-season snowbirds to be recent migrants.

The Florida survey suggested that $76 \%$ of snowbirds planned on returning to Florida the following year; ${ }^{6}$ however, no follow-up survey was performed. In our 10-year analysis, we observed that nearly half the people who filled a prescription for a travel supply in any season did so in the following season, and $78 \%$ of snowbirds in the $2009 / 10$ cohort were identified in 1 or more of the subsequent 9 seasons. Persistent snowbirds were younger and healthier, with an equal sex distribution, perhaps because increasing age, declining health and loss of a companion are potential deterrents to persistent migration to warmer destinations. 


\begin{tabular}{|c|c|c|c|}
\hline \multirow[b]{2}{*}{ Characteristic } & \multicolumn{2}{|c|}{ No. $(\%)$ of snowbirds* } & \multirow[b]{2}{*}{$\begin{array}{l}\text { Standardized } \\
\text { difference, \% }\end{array}$} \\
\hline & $\begin{array}{l}\text { Single-season } \\
n=11626\end{array}$ & $\begin{array}{l}\text { Persistent } † \\
n=41805\end{array}$ & \\
\hline \multicolumn{4}{|l|}{ Sociodemographic characteristics } \\
\hline \multicolumn{4}{|l|}{ Age category, yr } \\
\hline $65-69$ & $2817(24.2)$ & $13834(33.1)$ & 0.20 \\
\hline $70-74$ & $3139(27.0)$ & $12827(30.7)$ & 0.08 \\
\hline $75-79$ & $2744(23.6)$ & $8851(21.2)$ & 0.06 \\
\hline$\geq 80$ & $2926(25.2)$ & $6293(15.1)$ & 0.25 \\
\hline Female sex & $6292(54.1)$ & $21114(50.5)$ & 0.07 \\
\hline Recent migrant to Ontario & $1225(10.5)$ & $2702(6.5)$ & 0.15 \\
\hline Rural residency & 1565 (13.5) & $7885(18.9)$ & 0.15 \\
\hline Neighbourhood income quintile & & & 0.09 \\
\hline 1 (lowest) & $1960(16.9)$ & $5691(13.7)$ & 0.01 \\
\hline 2 & $2221(19.2)$ & $7753(18.6)$ & 0.02 \\
\hline 3 & $2336(20.2)$ & 8059 (19.3) & 0.03 \\
\hline 4 & $2394(20.7)$ & $9084(21.8)$ & 0.08 \\
\hline 5 (highest) & $2679(23.1)$ & $11078(26.6)$ & 0.20 \\
\hline Missing & $36(0.3)$ & $140(0.3)$ & 0.00 \\
\hline \multicolumn{4}{|l|}{ Comorbidities } \\
\hline \multicolumn{4}{|l|}{$\begin{array}{l}\text { Deyo-Charlson Comorbidity Index } \\
\text { score }\end{array}$} \\
\hline 0 & $8924(76.8)$ & $34072(81.5)$ & 0.12 \\
\hline 1 & $1135(9.8)$ & $3633(8.7)$ & 0.04 \\
\hline$\geq 2$ & $1567(13.5)$ & $4100(9.8)$ & 0.11 \\
\hline Diabetes mellitus & $3545(30.5)$ & $11815(28.3)$ & 0.05 \\
\hline Asthma & $1494(12.9)$ & $4821(11.5)$ & 0.04 \\
\hline $\begin{array}{l}\text { Chronic obstructive pulmonary } \\
\text { disease }\end{array}$ & $2128(18.3)$ & $6517(15.6)$ & 0.07 \\
\hline Hypertension & $8786(75.6)$ & $31290(74.8)$ & 0.02 \\
\hline Acute myocardial infarction & $486(4.2)$ & $1440(3.4)$ & 0.04 \\
\hline Congestive heart failure & $941(8.1)$ & $2099(5.0)$ & 0.12 \\
\hline Mental health condition & $2613(22.5)$ & $8175(19.6)$ & 0.07 \\
\hline \multicolumn{4}{|l|}{ Prior health care visits, median (IQR) } \\
\hline Emergency department (previous yr) & $11(7-16)$ & $9(6-14)$ & 0.15 \\
\hline Primary care (previous 2 yr) & $2(0-5)$ & $2(0-5)$ & 0.06 \\
\hline Specialist care (previous yr) & $0(0-0)$ & $0(0-0)$ & 0.13 \\
\hline \multicolumn{4}{|c|}{$\begin{array}{l}\text { Note: IQR = interquartile range. } \\
\text { "Except where noted otherwise. } \\
\text { †Those who appeared in } 2 \text { or more seasonal cohorts over the } 10 \text {-year study period. }\end{array}$} \\
\hline
\end{tabular}

Our findings have implications for health care system planners and research. We found that snowbirds consistently filled prescriptions for a median of 3 medications dispensed for a median of 180 days across study years. In an environment of drug shortages, ${ }^{25}$ this finding illustrates an acute demand for medications between October and December, which may contribute to a burdened system. Medication shortages may also deter snowbirds from travelling owing to potential loss of insurability. ${ }^{26}$

Furthermore, snowbirds often purchase private health insurance, given the limited out-of-country coverage provided by OHIP. 6,27-29 However, coverage requires that preexisting 


\begin{tabular}{|c|c|c|}
\hline \multirow[b]{2}{*}{ Characteristic } & \multicolumn{2}{|c|}{ Season; no. (\%) of snowbirds* } \\
\hline & $\begin{array}{c}2009 / 10 \\
n=53431\end{array}$ & $\begin{array}{c}2018 / 19 \\
n=65311\end{array}$ \\
\hline \multicolumn{3}{|l|}{ Month filled } \\
\hline September & $3806(7.1)$ & $4102(6.3)$ \\
\hline October & $19031(35.6)$ & $22596(34.6)$ \\
\hline November & $15315(28.7)$ & $20303(31.1)$ \\
\hline December & $11623(21.8)$ & $12958(19.8)$ \\
\hline January & $3656(6.8)$ & $5352(8.2)$ \\
\hline $\begin{array}{l}\text { No. of unique medications } \\
\text { filled, median (IQR) }\end{array}$ & $3(1-5)$ & $3(1-4)$ \\
\hline \multicolumn{3}{|c|}{ Most frequently prescribed drug classes } \\
\hline Statins & $24278(45.4)$ & $31430(48.1)$ \\
\hline $\begin{array}{l}\text { Angiotensin-converting- } \\
\text { enzyme inhibitors }\end{array}$ & $12811(24.0)$ & $12138(18.6)$ \\
\hline Calcium-channel blockers & $11880(22.2)$ & $14252(21.8)$ \\
\hline $\begin{array}{l}\text { Orally administered } \\
\text { antiglycemics }\end{array}$ & $11561(21.6)$ & $19803(30.3)$ \\
\hline$\beta$-blockers & $10676(20.0)$ & $11648(17.8)$ \\
\hline $\begin{array}{l}\text { Total days supplied, median } \\
\text { (IQR) }\end{array}$ & $180(150-184)$ & $180(150-180)$ \\
\hline $\begin{array}{l}\text { Note: IQR = interquartile range. } \\
{ }^{*} \text { Except where noted otherwise. }\end{array}$ & & \\
\hline
\end{tabular}

conditions be "stable and controlled," which also includes no changes to medications or dosages. ${ }^{30}$ Strict insurability rules may prompt older adults to delay changes in treatment until their return to Canada, which would leave them potentially vulnerable to medical complications. Indeed, we found that $0.6 \%$ of snowbirds died before accessing health care services, and a further $0.6 \%$ were admitted to hospital immediately after their migration gap.

We also observed that most snowbirds did not access government-funded health care services for nearly 5 months after their departure, which suggests substantial time spent outside of Canada. Snowbirds have reported improved quality of life and health benefits by escaping Canadian winters. ${ }^{23}$ Although they may be higher users of health care services before they depart and after they return, ${ }^{7}$ their time spent away may afford longer-term savings to a publicly funded health care system.

Canada's comprehensive health insurance coverage is an often-cited advantage of Canadian health administrative data, which are often used for research. ${ }^{31-35}$ These data are regularly used to improve our understanding of the health and health care needs of older adults. ${ }^{36,37}$ However, our finding that many older Ontarians are absent from the province for extended periods identifies a new and potentially important data gap that may need to be considered in future research. Gaps in follow-up are a form of temporary loss to follow-up that may
Table 4: Patterns of use of health care services by snowbirds in the 9-month period before (baseline) and after (migration) the receipt of a travel supply of medications, 2009/10 and 2018/19

\begin{tabular}{|ccc|}
\hline & \multicolumn{2}{c}{ Season; no. (\%) of snowbirds* } \\
\cline { 2 - 3 } Variable & $2009 / 10$ & $2018 / 19$ \\
$n=53431$ & $n=65311$
\end{tabular}

\section{Baseline period}

\begin{tabular}{lcc|}
\hline $\begin{array}{l}\text { No. of days on which health } \\
\text { care accessed, median (IQR) }\end{array}$ & $15(10-23)$ & $15(10-22)$ \\
\hline $\begin{array}{l}\text { Longest gap in consecutive } \\
\text { days on which health care } \\
\text { accessed, median (IQR), d }\end{array}$ & $50(35-72)$ & $53(36-75)$ \\
\hline Migration period & $10(6-15)$ & $10(6-15)$ \\
\hline $\begin{array}{l}\text { No. of days on which health } \\
\text { care accessed, median (IQR) }\end{array}$ & $145(107-180)$ & $147(110-178)$ \\
\hline $\begin{array}{l}\text { Longest gap in consecutive } \\
\text { days on which health care } \\
\text { accessed, median (IQR), d }\end{array}$ & & \\
\hline $\begin{array}{l}\text { Longest gap in consecutive } \\
\text { days on which health care } \\
\text { accessed, d }\end{array}$ & $1154(2.2)$ & $1485(2.3)$ \\
\hline $1-29$ & $2719(5.1)$ & $2330(3.6)$ \\
\hline $30-59$ & $4513(8.4)$ & $5440(8.3)$ \\
\hline $60-89$ & $8890(16.6)$ & $10956(16.8)$ \\
\hline $90-119$ & $10588(19.8)$ & $12878(19.7)$ \\
\hline $120-149$ & $25567(47.8)$ & $32222(49.3)$ \\
\hline$\geq 150$ & &
\end{tabular}

Service used on last day on which health care accessed before gap $\dagger$

\begin{tabular}{lcc} 
Medication fill & $34790(65.1)$ & $47013(72.0)$ \\
\hline Laboratory test & $3281(6.1)$ & $3147(4.8)$ \\
\hline Outpatient physician service & $27429(51.3)$ & $27936(42.8)$ \\
Inpatient physician service & $121(0.2)$ & $197(0.3)$
\end{tabular}

Characteristics of first health care accessed after migration gap

Month

\begin{tabular}{|lcc|}
\hline February & $2909(5.4)$ & $3415(5.2)$ \\
\hline March & $7053(13.2)$ & $7665(11.7)$ \\
\hline April & $21207(39.7)$ & $26761(41.0)$ \\
\hline May & $12347(23.1)$ & $15546(23.8)$ \\
\hline June & $3752(7.0)$ & $4371(6.7)$
\end{tabular}

Service†

Medication fill $27900(52.2) \quad 36633(56.1)$

Laboratory test $\quad 8270(15.5) \quad 11179(17.1)$

Outpatient physician service $34089(63.8) \quad 36998(56.6)$

Inpatient physician service $\quad 314(0.6) \quad 418(0.6)$

Death $338(0.6) \quad 366(0.6)$

Note: IQR = interquartile range.

${ }^{\star}$ Except where noted otherwise.

†Some people accessed more than 1 service. 
result in incomplete outcome ascertainment or bias. ${ }^{9,10}$ Appropriate methodologic management requires further study.

\section{Limitations}

As our methodology relied on use of prescription claims from Ontario, our findings may not be generalizable to older adults outside Ontario, where travel patterns may differ. Our approach also misses several subgroups of snowbirds. We were unable to capture snowbirds less than age 65, and our approach was limited to people who used prescription medications regularly, such as for chronic conditions. However, a recent Canadian Institute for Health Information report indicated that nearly $90 \%$ of older Ontarians take prescription medications for chronic conditions, ${ }^{14}$ so the majority of the population of interest would have been captured. We are also unable to capture those who were outside the country for less than 100 days, as they would not have qualified for a travel supply of medications.

Although proof of travel outside the province is required to receive travel supplies, ${ }^{12}$ we were unable to confirm that those who received travel supplies actually left Ontario. We observed that use of health care services was negligible during January to March; however, 14\% of those who received a travel supply in 2018/19 had a gap in accessing health care of less than 90 days, which is less than the duration of the travel supplies received. We were unable to discern from administrative data whether these people did not intend to travel at all, intended to travel for a shorter duration, intended to but were unable to travel, returned home temporarily or returned earlier than planned. Furthermore, owing to the administrative nature of our data, we were unable to determine the nature of the intended travel.

\section{Conclusion}

Migration to warmer destinations among older Ontarians remained mostly stable between 2009/10 and 2018/19. Migration patterns and sociodemographic characteristics of snowbirds also remained largely unchanged. Our results may be useful to health care system planners and care providers for resource and policy planning. Researchers are also encouraged to consider the snowbird population and the impact their absence from Ontario might have on evaluations that assume continuous observation.

\section{References}

1. Snowbird. Cambridge dictionary: English dictionary. Available: https://dictionary. cambridge.org/dictionary/english/snowbird (accessed 2019 Nov. 7).

2. Not your traditional snowbirds: Canadian snowbirds are travelling internationally. Etobicoke (ON): Ontario Blue Cross. Available: https://on.bluecross.ca/ images/docs/white-papers/not_your_traditional_snowbirds-on-en.pdf (accessed 2019 Nov. 7).

3. Coates KS, Healy R, Morrison WR. Tracking the snowbirds: seasonal migration from Canada to the U.S.A. and Mexico. Am Rev Can Stud 2002;32:433-50.

4. Kremmidas T. Flocking to the south this winter? Canadian snowbirds and the dollar. Canadian Business fournal [Burlington, ON]. Available: www.cbj.ca/ flocking-to-the-south-this-winter-canadian-snowbirds-and-the-dollar/ (accessed 2019 Nov. 7).

5. McHugh KE, Mings RC. Seasonal migration and health care. 7 Aging Health 1994;6:111-32.

6. Tucker RD, Marshall VW, Longino CF, et al. Older Anglophone Canadian snowbirds in Florida: a descriptive profile. Can J Aging 1988;7:218-32.

7. Forster J. Snowbirds: an unwelcome sign that winter's coming. CMAf 1998; 159:1356-8.
8. Daciuk JF, Marshall VW. Health concerns as a deterrent to seasonal migration of elderly Canadians. Soc Indic Res 1990;22:181-97.

9. Ontario Drug Benefit program: if you travel. Toronto: Ontario Ministry of Health. Available: http://health.gov.on.ca/en/public/programs/drugs/programs/ odb/opdp_travel_supply.aspx (accessed 2019 Nov. 7).

10. Ramage-Morin PL. Medication use among senior Canadians. Health Rep 2009; 20:37-44.

11. Drug use among seniors in Canada, 2016. Ottawa: Canadian Institute for Health Information; 2018. Available: https://secure.cihi.ca/free_products/drug -use-among-seniors-2016-en-web.pdf (accessed 2019 Nov. 7).

12. Get coverage for prescription drugs. Toronto: Government of Ontario. Available: www.ontario.ca/page/get-coverage-prescription-drugs (accessed 2019 Nov. 7).

13. Benchimol EI, Smeeth L, Guttmann A, et al.; RECORD Working Committee. The REporting of studies Conducted using Observational Routinelycollected health Data (RECORD) statement. PLoS Med 2015;12:e1001885.

14. Burden AM, Paterson JM, Gruneir A, et al. Adherence to osteoporosis pharmacotherapy is underestimated using days supply values in electronic pharmacy claims data. Pharmacoepidemiol Drug Saf 2015;24:67-74.

15. Happel SK, Hogan TD. Counting snowbirds: the importance of and the problems with estimating seasonal populations. Popul Res Policy Rev 2002;21:227-40.

16. Bérard-Chagnon J. Measuring emigration in Canada: review of available data sources and methods. Cat no 91F0015M. Ottawa: Statistics Canada; 2018. Available: www150.statcan.gc.ca/n1/pub/91f0015m/91f0015m2018001-eng.htm (accessed 2019 Nov. 7).

17. Austin P. Using the standardized difference to compare the prevalence of a binary variable between two groups in observational research. Commun Statistics Simulation Comput 2009;38:1228-34.

18. Travel between Canada and other countries, December 2018. Component of Statistics Canada catalogue no 11-001-X. Ottawa: Statistics Canada; 2019. Available: www150.statcan.gc.ca/n1/en/daily-quotidien/190221/dq190221c -eng.pdf?st=R528kNYh (accessed 2020 Feb. 21).

19. Martin HW, Hoppe SK, Marshall VW, et al. Sociodemographic and health characteristics of anglophone Canadian and U.S. snowbirds. 7 Aging Health 1992;4:500-13.

20. Marshall VW, Longino CF Jr, Tucker R, et al. Health care utilization of Canadian snowbirds: an example of strategic planning. F Aging Health 1989;1:150-68.

21. Mullins LC, Tucker RD, editors. Snowbirds in the Sun Belt: older Canadians in Florida. Tampa (FL): International Exchange Center on Gerontology; 1985.

22. Canadian megatrends: 150 years of immigration in Canada. Cat no 11-630-X. Ottawa: Statistics Canada; 2016. Available: www150.statcan.gc.ca/n1/pub/11 -630-x/11-630-x2016006-eng.htm (accessed 2020 Jan. 20).

23. Drug shortages have 'greatly increased' over the past 3-5 years say Canadian pharmacists [news release]. Ottawa: Canadian Pharmacists Association; 2019 July 26. Available: www.pharmacists.ca/news-events/news/drug-shortages-have -greatly-increased-over-the-past-3-5-years-say-canadian-pharmacists/ (accessed 2020 Feb. 21).

24. Shaver C. Drug shortages could ground snowbirds due to insurance issues. Chronicle Herald [Halifax] 2019 Aug. 26; Available: www.thechronicleherald.ca/ opinion/national-perspectives/dr-charles-shaver-drug-shortages-could-ground -snowbirds-due-to-insurance-issues-344594/ (accessed 2020 Feb. 22).

25. Korcok M. MDs should warn patients that an extended trek south may be expensive venture. CMA7 1992;147:1575-7.

26. OHIP out of country services. Toronto: Ontario Ministry of Health. Available: www.health.gov.on.ca/en/public/programs/ohip/outcountry_services.aspx (accessed 2020 Jan. 20).

27. CSA travellers' checklist. Toronto: Canadian Snowbird Association. Available: www.snowbirds.org/publications/csa-travellers-checklist/ (accessed 2020 Jan. 20).

28. 2020-2021 Travel Emergency Medical Insurance Policy. Toronto: Medipac Travel Insurance. Available: www.medipac.com/UserFiles/files/MedipacPolicyText.pdf (accessed 2020 Feb. 21)

29. Quan H, Smith M, Bartlett-Esquilant G, et al.; Hypertension Outcome and Surveillance Team. Mining administrative health databases to advance medical science: geographical considerations and untapped potential in Canada. Can 7 Cardiol 2012;28:152-4.

30. Lucyk K, Lu M, Sajobi T, et al. Administrative health data in Canada: lessons from history. BMC Med Inform Decis Mak 2015;15:69.

31. Suissa S, Garbe E. Primer: administrative health databases in observational studies of drug effects - advantages and disadvantages. Nat Clin Pract Rheumatol 2007;3:725-32.

32. Iron K, Lu H, Manuel D, et al. Using linked health administrative data to assess the clinical and healthcare system impact of chronic diseases in Ontario. Healthc Q 2011;14:23-7.

33. Smith AK, Ayanian JZ, Covinsky KE, et al. Conducting high-value secondary dataset analysis: an introductory guide and resources. $\mathcal{F}$ Gen Intern Med 2011; 26:920-9.

34. Doupe M, Shapiro E, Cloutier R. Healthcare services for an aging population: using administrative data to help prepare for the future. Healthc Policy 2011;6: 114-6.

35. Bronskill SE, Stevenson JE, Hirdes JP, et al.; Chartbook Advisory Group. Aging in Ontario: using population-based data in the evaluation of trends in health system use. Healthc Q 2011;14:21-5. 
36. von Allmen RS, Weiss S, Tevaearai HT, et al. Completeness of follow-up determines validity of study findings: results of a prospective repeated measures cohort study. PLoS One 2015;10:e0140817.

37. Kristman V, Manno M, Côté P. Loss to follow-up in cohort studies: How much is too much? Eur 7 Epidemiol 2004;19:751-60.

Affiliations: ICES Western (Shariff, Dixon, Garg, Clemens); Arthur Labatt Family School of Nursing (Shariff), Western University; Lawson Health Research Institute (Shariff, Garg, Clemens), London, Ont.; ICES Central (Paterson), Toronto, Ont.; Department of Family Medicine (Paterson), McMaster University, Hamilton, Ont.; Institute of Health Policy, Management and Evaluation (Paterson), University of Toronto, Toronto, Ont.; Department of Epidemiology and Biostatistics (Dixon, Garg), Western University, London, Ont.; Department of Mathematics and Statistics (Dixon), University of Guelph, Guelph, Ont.; Department of Medicine (Garg, Clemens), Western University; St. Joseph's Health Care London (Clemens), London, Ont.

Contributors: Salimah Shariff and Kristin Clemens conceived of and designed the study. Salimah Shariff drafted the manuscript. All of the authors contributed to data analysis and interpretation, revised the manuscript critically for important intellectual content, approved the final version to be published and agreed to be accountable for all aspects of the work.

Funding: This study was completed at the ICES Western site, which receives core funding from the Academic Medical Organization of Southwestern Ontario, the Schulich School of Medicine and Dentistry, Western University and the Lawson Health Research Institute. ICES is funded by an annual grant from the Ontario Ministry of Health. Amit Garg was supported by the Dr. Adam Linton Chair in Kidney Health Analytics and a Clinician Investigator Award from the Canadian Institutes of Health Research.

Content licence: This is an Open Access article distributed in accordance with the terms of the Creative Commons Attribution (CC BY-NC-ND 4.0) licence, which permits use, distribution and reproduction in any medium, provided that the original publication is properly cited, the use is noncommercial (i.e., research or educational use), and no modifications or adaptations are made. See: https://creativecommons.org/licenses/ by-nc-nd/4.0/.

Data sharing: The data set from this study is held securely in coded form at ICES. Although data-sharing agreements prohibit ICES from making the data set publicly available, access can be granted to those who meet prespecified criteria for confidential access, available at https://www.ices. on.ca/DAS.

Acknowledgements: The authors thank Andrea Belisle for her administrative support and IQVIA Solutions Canada for use of their Drug Information Database.

Disclaimer: Parts of this material are based on data and information compiled and provided by the Canadian Institute for Health Information. The opinions, results and conclusions reported in this paper are those of the authors and do not necessarily reflect those of the data providers or funding sources; no endorsement is intended or should be inferred.

Supplemental information: For reviewer comments and the original submission of this manuscript, please see www.cmajopen.ca/content/9/2/ E491/suppl/DC1. 